\title{
Chemical Characterization of Lebonan Cedar Tar
}

\section{Analiza kemijskog sastava katrana od libanonskog cedra}

\author{
Original scientific paper • Izvorni znanstveni rad \\ Received-prispjelo: 4. 2. 2016. \\ Accepted-prihvaćeno: 11. 5. 2017. \\ UDK: $630 * 813.4 ; 630 * 872.64 ; 674.032 .475 .842$ \\ doi:10.5552/drind.2017.1607
}

\begin{abstract}
Chemical characterization of Cedrus libani A. Rich tar, obtained by the traditional method and Jenkner Retort, was studied. Roots and fallen branches were used and analyzed separately. FID-GC and GC-MS were used for the characterization. The tar yield of Jenkner Retort was 60\%, while it is 30-40\% in the traditional method. 41 compounds were identified. $\beta$-himachalane (22-28\%) was found to be the main compound in all tars. $\alpha$-himachalane (6-10\%) and longifolene (7-9\%) were the other important compounds. Some compounds, which have antifungal and insecticides effects like deodarone and $E$ - $(\alpha)$-atlantone, were determined only in tars of roots. Phenolic compounds were not determined by the traditional method.
\end{abstract}

Key words: Cedrus libani, himachalane, pyrolysis, GC-MS, Jenkner Retort

SAŽETAK - U radu je prikazana analiza kemijskog sastava katrana od libanonskog cedra (Cedrus libani A. Rich) dobivenoga tradicionalnim postupkom i uz pomoć Jenknerove retorte. Napravljena je zasebna analiza za staro korijenje i za otpale grane libanonskog cedra. Za kemijsku karakterizaciju primijenjene su metode FID-GC i GC-MS. Prinos katrana uz pomoć Jenknerove retorte bio je $60 \%$, a prinos tradicionalnom metodom iznosio je $30-40 \%$. Pritom je identificiran 41 kemijski spoj. Ustanovljeno je da je $\beta$-himakalan (22-28\%) glavni spoj svih analiziranih katrana. Drugi po važnosti bili su A-himakalan (6-10\%) i longifolen (7 - $9 \%$ ). Neki spojevi koji imaju antifungalne i insekticidne učinke kao što su deodaron i E-( $\alpha$ )-atlanton pronađeni su samo u korijenju. $U$ katranu dobivenom tradicionalnim postupkom nisu pronađeni fenolni spojevi.

Ključne riječi: libanonski cedar, himakalan, piroliza, GC-MS, Jenknerova retorta

\section{INTRODUCTION 1. UVOD}

Pyrolysis is a thermal method converting biomass into gas, liquid and char product in the absence of oxygen. Sort of biomass and thermal conditions affect the yield of these products. Slow pyrolysis (low temperature, long residence time) enhances the charcoal yield, where in fast pyrolysis (moderate temperature, short residence time) liquid-tar yield is high (Bridgwater, 2003; Li et al., 2008; Wang et al., 2009)

Tar is a complex mixture which has a distinctive smoky smell and mainly dark brown color. Generally, Pinus sp., Juniperus sp., Fagus sp., Betula sp., Picea sp., and Cedrus sp. tree species are used for tar production. This liquid product has been used in wood preser-

\footnotetext{
${ }^{1}$ Author is associate professor at Bartin University, Forestry Faculty, Department of Forest Industry Engineering, Bartin, Turkey. ${ }^{2}$ Author is assistant at Karadeniz Technical University, Faculty of Forestry, Department of Forest Industry Engineering, Tarbzon, Turkey. ${ }^{3}$ Author is an employee of the company AHSAPSAN A.Ş, İstanbul, Turkey. ${ }^{4}$ Author is research \& development engineer in Kastamonu Entegre Ağaç San. ve Tic. A.Ş., Istanbul, Turkey.

Autor je izvanredni profesor Sveučilišta u Bartinu, Šumarski fakultet, Odjel za inženjerstvo industrije na bazi drva, Bartin, Turska. ${ }^{2}$ Autor je profesor Tehničkog sveučilišta u Karadenizu, Šumarski fakultet, Odjel za inženjerstvo industrije na bazi drva, Tarbzon, Turska. ${ }^{3}$ Autor je zaposlenik tvrtke AHSAPSAN A. Ş., İstanbul, Turkey. ${ }^{4}$ Autor je inženjer za istraživanje i razvoj u tvrtki Kastamonu Entegre Ağaç San. ve Tic. A. Ş., Istanbul, Turkey.
} 
vation since ancient times specially in the impregnation of ships and boats (Reunanen et al., 1989; Reunanen et al., 1990; Reunanen et al., 1993).

It was also widely used in veterinary as an antiseptic that is applied to wounds and scratches, treatment for intestinal parasites by adding some drops to drinking water and as repellent against insects and snakes. There are also some applications for the human health care eg. ulcers, dandruff, eczema (Kurt et al., 2008). Despite its distinctive smell and some toxic effect, inhaling of tar helps asthma and, especially in Marrakesh, it is believed to keep away Satan from small babies (Julin, 2008). Tars can be burned as fuel, too (Bridgwater, 2003).

Lebanon Cedar (Cedrus libani A. Rich) is a native Mediterranean species with a pleasant odor and valuable wood. In the ancient times, it had a religious meaning and was used as a medicine (Hafizoglu, 1987a). Today there is a legal restriction to cut these trees. Nonetheless, villagers use the fallen branches and old roots to produce cedar tar.

In the last decade, pyrolysis of woody plants has been studied by modern methods from different aspects because of its advantage in storage and variable use (Chiodo et al., 2015; Das and Sarmah, 2015; Hagner et al., 2015; Niu and Liu, 2015; Lij et al., 2015; St Pierre et al., 2015). However, traditional tar production has been used for several millennia. From this point of view, the aim was to compare the tar composition obtained by traditional and modern pyrolysis methods and also to determine the difference between root and branch wood of a tree.

\section{MATERIALS AND METHODS \\ 2. MATERIJALI I METODE}

\subsection{Materials}

2.1. Materijali

In this study, Lebanon Cedar (Cedrus libani A. Rich), a native species in Turkey, was used for tar production. Due to the legal restrictions of Cedar wood production, fallen branches and old roots were used. Samples were taken at the altitude of $1400 \mathrm{~m}$ from Büyüknacar-Pazarcık, Kahramanmaraş, Turkey. The moisture content of branches and roots were $5.83 \%$ and $7.5 \%$, respectively. Traditionally obtained tar was taken from the same location and parts of tree.

\subsection{Method}

\subsection{Metoda}

\subsubsection{Sample preparation}

2.2.1. Priprema uzoraka

Two different methods, Traditional and Jenkner Retort, were used for tar production in this study. Traditional method, which is in principle a kind of distillation, was applied by the local people. $400-500 \mathrm{~kg} \mathrm{sam}-$ ple was used in this method. Two holes with different dimensions, depending on the amount of wood material used, were dug nearby and generally the smaller, where tar is collected, was located down-slope from the larger. A pipe was placed between two holes for the tar flow. Inner and upper part of the hole, where ignition occurs, were plastered with mud and clay. If required, small holes were opened on the top to keep the burning process active. For a better tar yield, wood samples were inserted vertically in the hole (Hjulstrom et al., 2006; Kurt et al., 2008). Jenkner Retort was used for the pyrolysis of cedar samples. A cylindrical stainless steel reactor with $12 \mathrm{~cm}$ internal diameter and 26 $\mathrm{cm}$ height was used. The temperature of retort was measured by Pt-Rh-Pt thermocouple. Branches and roots were applied separately. For each sample, approximately $600 \mathrm{~g}$ was placed in the reactor and heated by electric furnace. With the rate of $4{ }^{\circ} \mathrm{C} / \mathrm{min}$, temperature raised to $\max .400{ }^{\circ} \mathrm{C}$. Bio-char, end-product, was weighted after the experiment and gas yield was calculated by taking the difference (Sutcu et al., 2004). Three repetitions were done for each experiment.

\subsubsection{Characterization \\ 2.2.2. Karakterizacija}

For the chemical analysis, three different solvents, n-hexane, diethyl ether and dichloromethane, were used for the liquid-liquid extraction. $5 \mathrm{ml}$ tar was extacted with $30 \mathrm{ml}$ solvent and diluted to $100 \mathrm{ml} .1 \mathrm{ml}$ aliquot was taken from the diluted sample and evaporated under the nitrogen before silylation (Ekman and Holmbom, 1989). Silylated samples were analyzed by FID-GC (Flame Ionization Detector - Gas Chromatography) (Shimadzu GC-2010) and GC-MS (Gas Chromatography - Mass Spectrometry) (Shimadzu GCMS2010 Plus) equipped with TRB-5 type column $30 \mathrm{~m} \mathrm{x}$ $0.25 \mathrm{~mm}(0.25 \mu \mathrm{m}$ film thickness). Helium was used as carrier gas with $1.03 \mathrm{ml} / \mathrm{min}$ flow. Temperature program was $60{ }^{\circ} \mathrm{C}\left(1 \mathrm{~min}\right.$.) raised to $120^{\circ} \mathrm{C}$ with the rate of $4^{\circ} \mathrm{C} / \mathrm{min}$ and held for $10 \mathrm{~min}$. with the same rate raised to $200^{\circ} \mathrm{C}$ (held $10 \mathrm{~min}$.) and then to $300^{\circ} \mathrm{C}$ (held $10 \mathrm{~min}$.). Detector temperature was $300^{\circ} \mathrm{C}$. Split ratio was 1:10. Three injections were done for each sample.

\section{RESULTS AND DISCUSSION}

\section{REZUTATI I RASPRAVA}

\subsection{Product yields}

3.1. Prinos proizvoda

In the traditional method, the yield was $30-40 \%$ $(150-200 \mathrm{~kg} \operatorname{tar} / 400-500 \mathrm{~kg}$ wood material), while with Jenkner Retort system it was $60 \%$. When modern closed systems are used, it is possible to control and apply high temperatures, which affect the yield. The temperature is an important parameter affecting the yield of pyrolysis products (Duman et al., 2011; Ozciftci and Özbay, 2013). Table 1 presents the yield of Jenkner Retort products. As seen, tar is the main product. Tar was obtained at $230^{\circ} \mathrm{C}$ from branches and at $300{ }^{\circ} \mathrm{C}$ from roots. No significant difference was observed between the yield of roots and branches.

According to Koch P. (1972), with destructive distillation, the yield of char was found as 15-20\% and $6-12 \%$ of tar in southern pine stump wood.

During the process, two different colors of tar were observed. Dark black color was from resinous roots and 
Table 1 Yield of Jenkner Retort products, \%

Tablica 1. Prinos proizvoda Jenknerovom retortom, \%

\begin{tabular}{|l|c|c|c|}
\hline & $\begin{array}{c}\text { Gas } \\
\text { Plin }\end{array}$ & $\begin{array}{c}\text { Liquid (Tar) } \\
\text { Tekućina (katran) }\end{array}$ & $\begin{array}{c}\text { Char } \\
\text { Ugljen }\end{array}$ \\
\hline Root / Korijen & 12.2 & 62.1 & 25.6 \\
\hline Branch / Grane & 11 & 64.5 & 24.4 \\
\hline
\end{tabular}

yellow color from branches. Unfortunately, the gas product cannot be used as in the closed Jenkner Retort system.

\subsection{Analysis of tars \\ 3.2. Analiza katrana}

Cedar tar, obtained with different methods and from different parts of wood, was analyzed by GC-MS and FID-GC. Chemical composition of tars is shown in
Table 2. Phenols, alcohols, acids, sesquiterpenoids and fatty-resin acids are the constituents of tars with different ratios. Almost $70 \%$ of tar produced by Jenkner Retort was identified; however, this ratio was $50 \%$ in the traditional method.

$\beta$-himachalane (22-28\%), a sesquiterpene, is the most abundant compound in all tars. It is found to be higher in the branches. $\alpha$-himachalane $(6-10 \%)$ and longifolene (7-9 \%) are the other important compounds. As known, $\beta$-himachalane and its derivates obtained from cedrus have antifungal and insecticidal effects (Daoubi et al., 2005; Derwich et al., 2010; Singh and Agarwal, 1988). Although the results showed similarities with literature, himachalol, which was found in the essential oil of cedar wood obtained by
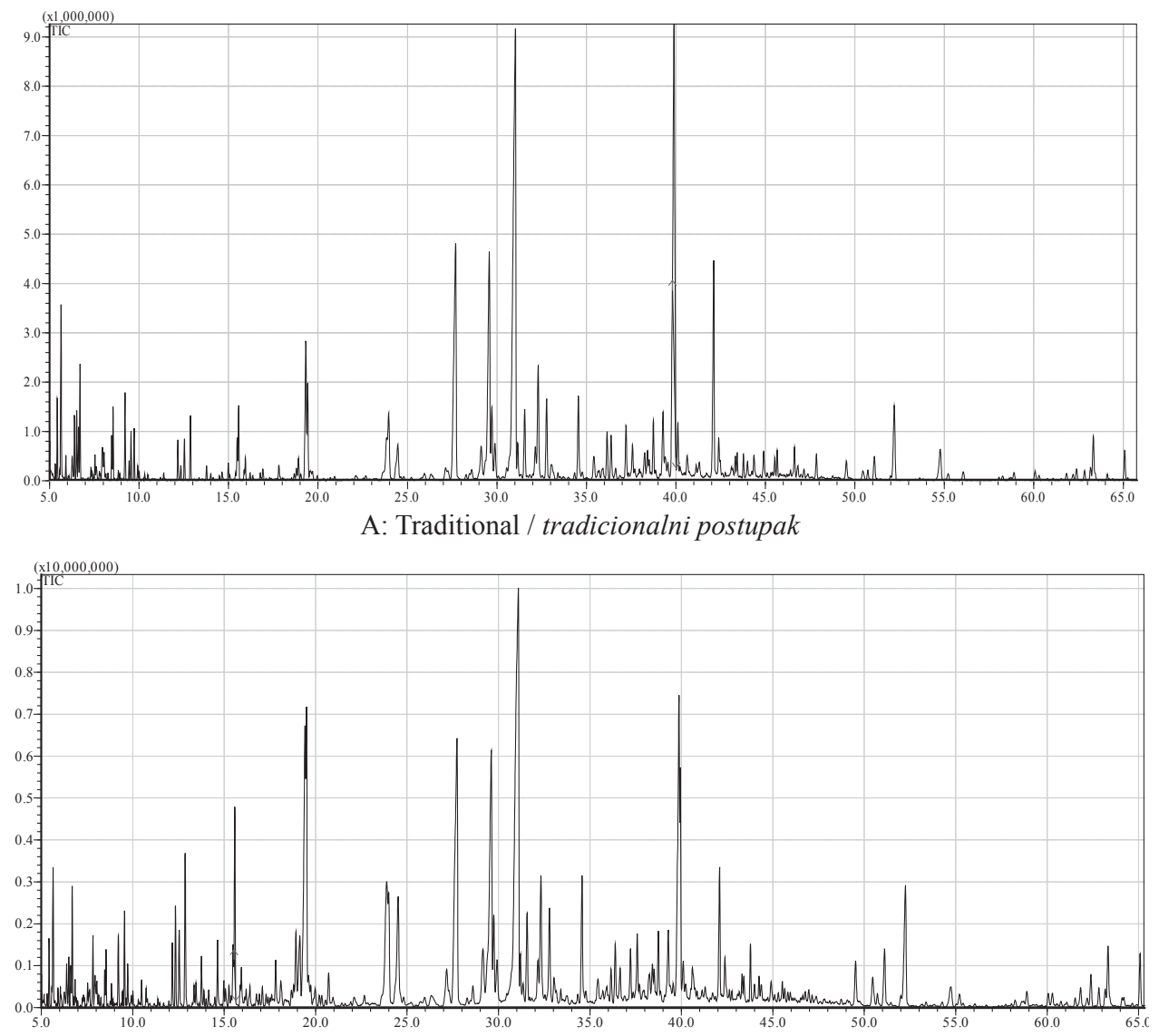

B: Jenkner Retort - branch / u Jenknerovoj retorti - grane

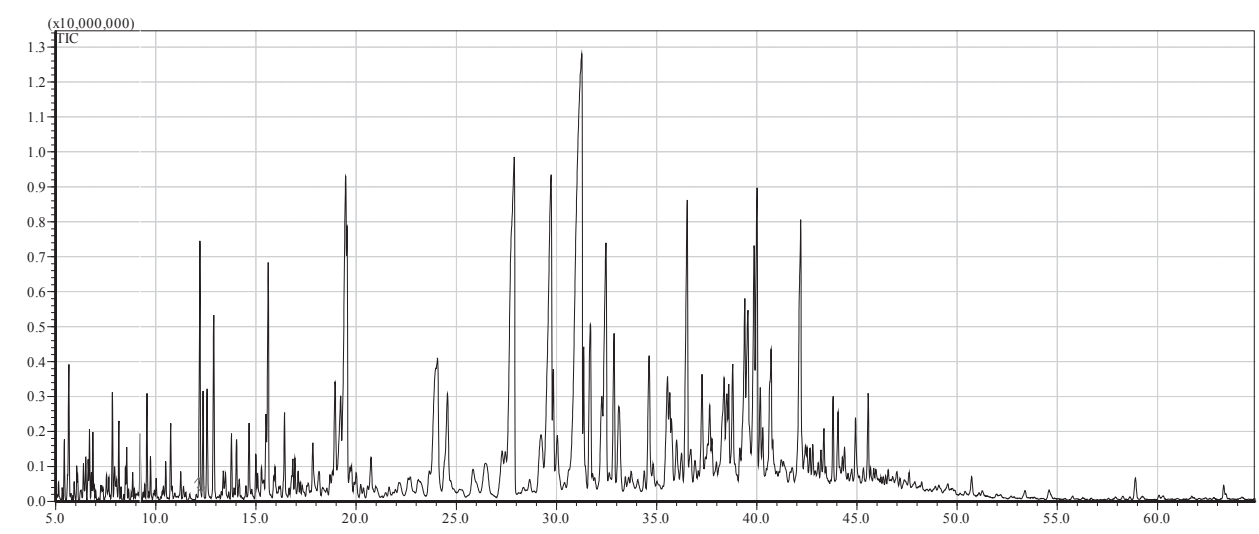

C: Jenkner Retort - root / u Jenknerovoj retorti - grane

Figure $1 \mathrm{GC}-\mathrm{MS}$ Chromatograms of cedrus tar diluted in dichloromethane

Slika 1. GC-MS kromatogrami katrana od cedra razrijeđenoga u diklormetanu 
Table 2 Chemical composition of Cedrus libani tar obtained by different methods, \%

Tablica 2. Kemijski sastav katrana od libanonskog cedra proizvedenoga različitim metodama, \%

\begin{tabular}{|c|c|c|c|c|c|c|c|c|c|c|}
\hline \multirow[t]{2}{*}{$\begin{array}{l}\text { Compound } \\
\text { Kemijski spoj }\end{array}$} & \multirow[t]{2}{*}{ RT } & \multicolumn{3}{|c|}{$\begin{array}{l}\text { Root (Jenkner } \\
\text { Retort) } \\
\text { Korijen ( } u \\
\text { Jenknerovoj } \\
\text { retorti) } \\
\end{array}$} & \multicolumn{3}{|c|}{$\begin{array}{c}\text { Branch (Jenkner } \\
\text { Retort) } \\
\text { Grane }(u \\
\text { Jenknerovoj } \\
\text { retorti) }\end{array}$} & \multicolumn{3}{|c|}{$\begin{array}{l}\text { Traditional } \\
\text { Tradicionalni } \\
\text { postupak }\end{array}$} \\
\hline & & A & B & $\mathrm{C}$ & A & $\mathrm{B}$ & $\mathrm{C}$ & A & $\mathrm{B}$ & $\mathrm{C}$ \\
\hline 3-methyl-3-butanoic acid / 3-metil-3-maslačna kiselina & 10.32 & 0.31 & 0.13 & 0.34 & 0.47 & 0.80 & 0.54 & - & 0.84 & 1.28 \\
\hline Phenol / fenol & 13.67 & 0.31 & 0.25 & 0.11 & - & 0.16 & 0.44 & 0.13 & - & - \\
\hline Propanoic acid / propanoična kiselina & 14.02 & - & - & 0.11 & - & - & - & - & - & - \\
\hline Acetic acid / octena kiselina & 14.56 & - & 0.05 & 0.37 & - & 0.36 & - & - & - & - \\
\hline 2,6-Dimethyl styrene / 2,6-dimetil stiren & 15.07 & 0.31 & 0.24 & - & - & - & - & - & - & - \\
\hline p-Cresol-1 / p-krezol-1 & 17.02 & 0.23 & 0.31 & - & 0.21 & 0.29 & 0.34 & - & - & - \\
\hline p-Cresol-2 / p-krezol-2 & 17.44 & 0.47 & 0.75 & 0.64 & 0.34 & 0.38 & 0.65 & - & - & - \\
\hline 1,3-methyl phenyl ethanone / 1,3-metil fenil etanon & 19.06 & 0.27 & 0.32 & - & - & - & - & - & - & - \\
\hline 2,4-dimethyl phenol / 2,4-dimetil fenol & 21.06 & 0.25 & 0.29 & 0.28 & 0.28 & 0.30 & 0.28 & - & - & - \\
\hline Guaiacol / gvajakol & 21.23 & 0.99 & 1.23 & 0.44 & 0.68 & 0.19 & 1.61 & - & - & - \\
\hline 2,6-dimethylphenoxy / 2,6-dimetilfenoksi & 23.46 & 0.05 & - & - & - & - & - & - & - & - \\
\hline 4-methyl-guaiacol / 4-metil-gvajakol & 27.70 & - & - & 2.97 & 2.89 & 2.95 & 5.79 & 0.29 & 2.63 & 1.11 \\
\hline $\begin{array}{l}\text { 4-methyl-guaiacol+catechol* } \\
\text { 4-metil-gvajakol+katehol* }\end{array}$ & 27.75 & 3.04 & 5.13 & - & - & - & - & - & - & - \\
\hline Catechol / katehol & 27.79 & - & - & 1.57 & - & 4.96 & 2.22 & 0.36 & 0.94 & 1.34 \\
\hline 4-methyl-catechol / 4-metil-katehol & 32.43 & 0.38 & 1.41 & 1.78 & - & 6.70 & 3.76 & 0.84 & 1.87 & 2.09 \\
\hline 3-methyl-catechol / 4-metil-katehol & 33.20 & - & - & - & 0.48 & - & - & - & - & - \\
\hline$\alpha$-Himachalane / $\alpha$-himakalan & 35.70 & 9.41 & 8.78 & 7.48 & 10.1 & 6.01 & 9.22 & 6.57 & 10.1 & 7.29 \\
\hline Longifolene / longifolen & 37.07 & 8.75 & 7.73 & 7.22 & 9.70 & 7.11 & 8.75 & 7.69 & 9.40 & 7.80 \\
\hline Cedren / cedren & 37.16 & - & 0.63 & 0.64 & 1.24 & 1.02 & 1.24 & 1.25 & 1.39 & 1.16 \\
\hline$\beta$-Himachalane / $\beta$-himakalan & 38.30 & 25.1 & 22.5 & 21.9 & 28.1 & 23.1 & 25.8 & 23.7 & 25.8 & 23.0 \\
\hline$(+)$-Cuparane / (+)-kuparan & 38.59 & 2.26 & 1.99 & 2.33 & 1.61 & 1.11 & 1.49 & - & - & - \\
\hline iso-longifolene / izo-longifolen & 39.10 & 1.05 & 1.05 & 1.13 & 0.64 & - & - & 0.59 & 0.53 & 0.59 \\
\hline iso-Eugenol / izo-eugenol & 40.79 & 1.26 & 1.23 & 1.57 & 2.05 & 2.44 & 1.84 & 1.56 & 1.39 & 1.50 \\
\hline Dihydro-Ar-Tumerone / dihidro-ar-tumeron & 42.12 & 0.87 & 1.55 & 1.52 & - & - & - & - & - & - \\
\hline$\beta$-Himachalenoxide / $\beta$-himakalenoksid & 42.55 & - & - & - & - & - & - & 1.22 & 1.00 & 1.11 \\
\hline Ar-tumerone / Ar-tumeron & 44.39 & 1.98 & 1.74 & 2.05 & 0.61 & 0.99 & 0.36 & - & - & - \\
\hline$\beta$-Atlantone / $\beta$-atlanton & 44.56 & 0.85 & 1.43 & 1.05 & - & - & - & - & - & - \\
\hline Tumerone / tumeron & 45.35 & 1.82 & 1.53 & 1.82 & 0.98 & 0.99 & 0.86 & 1.73 & 1.23 & 1.50 \\
\hline Deodarone / deodaron & 45.67 & 2.40 & 2.06 & 2.31 & - & - & - & - & - & - \\
\hline E- $(\alpha)$-Atlantone / E- $(\alpha)$-atlanton & 48.29 & 3.55 & 3.46 & 4.21 & - & - & - & - & - & - \\
\hline 16:0 acid / 16:0 kiselina & 60.23 & $\operatorname{tr}$ & $\operatorname{tr}$ & $\operatorname{tr}$ & $\operatorname{tr}$ & $\operatorname{tr}$ & $\operatorname{tr}$ & $\operatorname{tr}$ & $\operatorname{tr}$ & $\operatorname{tr}$ \\
\hline Dehydroabietan dehidroabietan & 61.33 & - & - & - & 1.87 & 2.86 & 1.84 & - & - & - \\
\hline 9-18:1 acid / 9-18:1 kiselina & 66.94 & $\operatorname{tr}$ & $\operatorname{tr}$ & $\operatorname{tr}$ & $\operatorname{tr}$ & $\operatorname{tr}$ & $\operatorname{tr}$ & $\operatorname{tr}$ & - & $\operatorname{tr}$ \\
\hline Pimaric acid / pimarinska kiselina & 70.74 & - & - & - & 0.58 & 0.35 & - & - & - & - \\
\hline Sandrocopimaric acid / sandrokopimarna kiselina & 71.11 & $\operatorname{tr}$ & $\operatorname{tr}$ & $\operatorname{tr}$ & - & 0.28 & 0.16 & $\operatorname{tr}$ & $\operatorname{tr}$ & - \\
\hline iso-Pimaric acid / izo-pimarinska kiselina & 71.22 & $\operatorname{tr}$ & $\operatorname{tr}$ & $\operatorname{tr}$ & 1.62 & 1.50 & 1.36 & 1.70 & 1.27 & 1.58 \\
\hline Dehydroabietic acid / dehidroabietična kiselina & 72.53 & $\operatorname{tr}$ & $\operatorname{tr}$ & $\operatorname{tr}$ & 1.09 & 1.28 & 1.04 & 1.01 & 0.74 & 0.90 \\
\hline Abietic acid / abietična kiselina & 73.36 & - & - & - & - & - & - & 0.70 & 0.52 & 0.64 \\
\hline 22:0 acid / 22:0 kiselina & 78.33 & $\operatorname{tr}$ & $\operatorname{tr}$ & $\operatorname{tr}$ & $\operatorname{tr}$ & $\operatorname{tr}$ & $\operatorname{tr}$ & $\operatorname{tr}$ & $\operatorname{tr}$ & $\operatorname{tr}$ \\
\hline 24:0 alcohol / 24:0 alkohol & 80.67 & $\operatorname{tr}$ & $\operatorname{tr}$ & $\operatorname{tr}$ & $\operatorname{tr}$ & $\operatorname{tr}$ & $\operatorname{tr}$ & $\operatorname{tr}$ & $\operatorname{tr}$ & $\operatorname{tr}$ \\
\hline 24: acid / 24:0 kiselina & 81.53 & $\operatorname{tr}$ & $\operatorname{tr}$ & $\operatorname{tr}$ & $\operatorname{tr}$ & $\operatorname{tr}$ & $\operatorname{tr}$ & $\operatorname{tr}$ & $\operatorname{tr}$ & $\operatorname{tr}$ \\
\hline $\begin{array}{l}\text { Total non-identified compounds } \\
\text { Ukupno neidentificirani spojevi }\end{array}$ & & 33.1 & 32.4 & 35.3 & 33.5 & 28.1 & 33.1 & 50.6 & 40.3 & 47.1 \\
\hline
\end{tabular}

tr: trace (<\% 0.1) A: n-Hexane, B:Diethylether, C:Dichloromethane, RT: TRB-5 type column,*:were not seperated. tr: u tragovima $(<0,1 \%)$ A: n-heksan, B: dietileter, C: diklormetan, RT: TRB-5 kolona, *: nisu izdvojeni. 
Clevenger apparatus at $100{ }^{\circ} \mathrm{C}$ (Hafizoglu, 1987b; Fleisher and Fleisher, 2000; Saab et al., 2005), was not detected in our samples. $\beta$-himachalenoxide was only determined by the traditional method.

Likewise the yield, the composition of tar also differs with thermal conditions (Wang et al., 2009). Phenols, guaicol, creosol and 2.4-dimethyl phenol, were clearly observed only in the Jenkner Retort system. These compounds indicated that temperature applied in the traditional method was not sufficient for lignin degradation. Another compound iso-eugenol, precursors of lignin biosynthesis, was determined almost more than $2 \%$ in the branches. As known, in the softwood branches, the lignin content was higher (Fengel and Wegener, 2003). Phenols, obtained from biomass pyrolysis oils are valuable chemicals. They have disinfectant and antidiarrheal characteristics. They are also used as intermediates in synthesis of pharmaceutical products, adhesives and special polymers (AmenChen et al., 1997; Ozbay, 2015).

Resin and fatty acids were found in all samples, while in roots they were less than $0.01 \%$ (trace). Catechol, used in the production of pesticides, was found in higher amounts $(2.2-6.7 \%)$ in the tars obtained from branches.

Deodarone, E- $(\alpha)$-atlantone, dihydro-Ar-tumore, which have an antifungal and insecticides effect, were found only in roots (Satrani et al., 2006; Chaudhary et $a l ., 2012$ ). Another compound, tumorene, used as a repellent against mosquito larvae, was identified in all tars (Champakaew et al., 2007).

Three solvents with different polarities were used to dissolve tars for the analysis (Fig. 1). Although no significant difference was observed, dichloromethane gave the highest yield (59.6-71.8\%) of solubility among the identified compounds. However, $\beta$-himachalane, the main compound, was found to be higher in the hexane extract.

\section{CONCLUSION}

\section{ZAKLJUČAK}

In this study, chemical characterization of Cedrus libani A. Rich tar obtained by pyrolysis with Jenkner Retort system and traditional method was studied. Roots and fallen branches were used and analyzed separately. The tar yield of Jenkner Retort was $60 \%$, while it is 30$40 \%$ in the traditional method, which revealed the effect of temperature. 41 compounds were identified. Phenols, alcohols, acids, sesquiterpenoids and fatty-resin acids are the main constituents. Phenols and methoxy groups were seen only in Jenkner Retort system. However, sesquiterpenoids ( $\beta$-himachalane, $\alpha$ - himachalane), used for veterinary purposes, were determined in all samples. Traditional method can be used by the local veterinary, if compounds that have antifungal and insecticides are determined in these samples.

\section{Acknowledgments - Zahvala}

The authors would like to thank to Prof. Dr. Ihsan TOROGLU, Bülent Ecevit University, for using Jenkner
Retort System and to local people of Pazarcik, Kahramanmaraş, Turkey for performing traditional method.

\section{REFERENCES}

\section{LITERATURA}

1. Amen-Chen, C.; Padel, H.; Roy, C., 1997: Separation of phenols from Eucalyptus wood tar. Biomass and Bioenergy, 13(1/2): 25-37. https://doi.org/10.1016/S09619534(97)00021-4.

2. Bridgwater, A. V., 2003: Renewable fuels and chemicals by thermal processing of biomass. Chemical Engineering Journal, 91(2-3): 87-102.

https://doi.org/10.1016/S1385-8947(02)00142-0.

3. Champakaew, D.; Choochote, W.; Pongpaibul, Y.; Chaithong, U.; Jitpakdi, A.; Tuetun, B.; Pitasawat, B., 2007: Larvicidal efficacy and biological stability of a botanical natural product zedoary oil-impregnated sand granules against Aedes aegypti (Diptera, Culicidae). Parasitology Research, 100(4): 729-737. https://doi.org/10.1007/s00436-006-0350-5.

4. Chaudhary, A.; Sood, S.; Kaur, P.; Kumar, N.; Thakur, A.; Gulati, A.; Singh, B., 2012: Antifungal sesquiterpenes from Cedrus deodara.Planta Medica, 78(2): 186-188. https://doi.org/10.1055/s-0031-1280264.

5. Chiodo, V.; Zafarana, G.; Maisano, S.; Freni, S.; Urbani, F., 2015: Pyrolysis of different biomass: Direct comparisonamong Posidonia Oceanicai Lacustrine Alga and White-Pine. Fuel, 164: 220-227. https://doi.org/10.1016/j.fuel.2015.09.093.

6. Das, O.; Sarmah, A. K., 2015: Mechanism of waste biomass pyrolysis: Effcet of pysical and chemical pre-treatments. Science of the Total Enviroment, 537: 323-334. https://doi.org/10.1016/j.scitotenv.2015.07.076.

7. Daoub1, M.; Hernaandez-Galaa, R.; Benharref, A.; Collado, I., 2005: Screening Study of Lead Compounds for Natural Product-Based Fungicides: Antifungal Activity and Biotransformation of 6r,7r-Dihydroxy-â-himachalene by Botrytis cinerea. J. Agric. Food Chem, 53: 66736677. https://doi.org/10.1021/jf050697d.

8. Derwich, E.; Benziane, Z.; Boukir., A., 2010: Chemical composition and In vitro antibacterial activity of the essential oil of Cedrus atlantica. Int. J. Agric. Biol., 12: 381-385.

9. Duman, G.; Okutucu, C.; Uçar, S.; Stahl, R.; Yanık, J., 2011: The slow and fast pyrolysis of cherry seed. Bioresource Technology, 102: 1869-1878. https://doi.org/10.1016/j.biortech.2010.07.051.

10. Ekman, R.; Holmbom, B., 1989: Analysis by gas chromatography of wood extractives in wood and pulp samples from mechanical pulping of spruce. Nordic Pulp Paper Res J, 41:16-24.

https://doi.org/10.3183/NPPRJ-1989-04-01-p016-024.

11. Fengel, D.; Wegener, G., 2003: Wood Chemistry, Ultrastructure, Reactions. Verlag Kessel.

12. Fleisher, A.; Fleisher, Z., 2000. The volatiles of the leaves and wood of Lebanon Cedar (Cedrus libani A.Rich) aromatic plants of the Holy Land and the Sinai.Part XIV. Journal of Essential oil Research, 12(6): 763-765. https://doi.org/10.1080/10412905.2000.9712210.

13. Hafizoğlu, H., 1987a: Extractive constituents of Cedrus libani. Karadeniz Teknik University Forestry Faculty Journal, 10(1-2): 91-97.

14. Hafizoğlu, H., 1987b. Studies on the chemistry of Cedrus libani A. Rich. I. Wood extractives of Cedrus libani. Holzforschung, 41 (1): 27-38.

https://doi.org/10.1515/hfsg.1987.41.1.27. 
15. Hagner, M.; Hallman, S.; Jauhiainen, L.; Kemppainen, R.; Ramo, S.; Tiilikkala, K.; Setala, H., 2015: Birch (Betula spp.) wood biochar is a potential soil amendment to reduce glyphose leaching in agricultural soils. Journal of Environment Management, 164: 46-52. http://dx.doi.org/10.1016/j.envman.2015.08.039.

16. Hjulstrom, B.; Isaksson, S.; Hennius, A., 2006: Organic geochemical evidence for pine tar production in Middle Eastern Sweden during the Roman iron Age. J. Archaeol Sci., 33: 283-294. https://doi.org/10.1016/j.jas.2005.06.017.

17. Julin, M., 2008: Tar production-traditional medicine and potential threat to biodiversity in the Marrakesh region. An ethnobotanical study. Uppsala University. Degree Project in biology, Sweden.

18. Koch, P., 1972: Utilization of The Southern Pines, Vol II: Processing, Agriculture Handbook, USA, No: 420, pp. 1485.

19. Kurt, Y.; Kaçar, M. S.; Isık, K., 2008: Traditional Tar production from Cedrus libani A.Rich on the Taurus Mountains in Southern Turkey. Economic Botany, 62(4): 615620. https://doi.org/10.1007/s12231-008-9023-x.

20. Li, J.; Yan, R.; Xiao, B.; Liang, T. D.; Lee, D. H., 2008: Preparation of Nano-NiO particles and evaluation of their catalytic activity in pyrolyzing biomass components. Energy\&Fuels, 22(1): 16-23. https://doi.org/10.1021/ef700283j.

21. Li, J.; Paul, M. C.; Younger, P. L.; Watson, I.; Hossain, M.; Welch, S., 2015: Characterization of biomass combustion at high temperatures based on an upgraded single particle model. Applied Energy, 156: 749-755. https://doi.org/10.1016/j.apenergy.2015.04.027.

22. Niu, H. C.; Liu, N. A., 2015: Thermal decomposition of pine branch:Unified kinetic model on pyrolytic reactions in pyrolysis and combustion. Fuel, 160: 339-345. https://doi.org/10.1016/j.fuel.2015.07.108.

23. Reunanen, M.; Raine, E.; Markku, H., 1989: Analysis of Finnish Pine Tar and Tar from the Wreck of Frigate St. Nikolai. Holzforschung, 43: 33-39. https://doi.org/10.1515/hfsg.1989.43.1.33.

24. Reunanen, M.; Raine, E.; Markku, H., 1990: Long-term Alteration of Pine Tar in a Marine Enviroment. Holzforschung, 44: 277-278.

https://doi.org/10.1515/hfsg.1990.44.4.277.

25. Reunanen, M.; Holmbom, B.; Edgren, T., 1993: Analysis of Archaeological Birch Bark Pitches. Holzforschung, 47: 175-177. https://doi.org/10.1515/hfsg.1993.47.2.175.
26. Ozbay, G., 2015: Pyrolysis of Firwood (Abies bornmüllerianaMattf.) Sawdust: Characterization of Bio-Oil and Bio-Char. Drvna industrija, 66(2): 105-114. https://doi.org/10.5552/drind.2015.1359.

27. Ozcifci, A.; Özbay, G., 2013: Bio-oil production from catalytic pyrolysis method of furniture industry sawdust. Journal of the Faculty of Engineering and Architecture of Gazi University, 28(3): 473-479.

28. Saab, A.M.; Harb, F.Y.; Koenig, W.A., 2005: Essential oil components in heart wood of Cedrus libani and $\mathrm{Ce}$ drus atlantica from Lebanon. Minerva Biotecnologica, 17(3): 159-161.

29. Satrani, B.; Aberchane, M.; Farah, A.; Chaouch, A.; Talbi, M., 2006: Composition chimique et activite antimicrobienne des huiles essentielles extraites par hydrodistillation fractionnee du bois de Cedrsu atlantica Manetti. Acta Botanica Gallica: Botany Letters, 153(1): 97-104. https://doi.org/10.1080/12538078.2006.10515524.

30. Singh, D.; Agarwal, S. K., 1988: Himachalol and $\beta$-himachalene: Insecticidal principles of himalayan cedarwood oil. J Chem Ecol., 14(4): 1145-1151. https://doi.org/10.1007/BF01019342.

31. Sutcu, H.; Toroglu, I.; Piskin, S., 2004: High Temperature Carbonization of Turkish Bituminous Coals in Jenkner Retort, Energy Sources, 26(7): 671-683. https://doi.org/10.1080/00908310490445544.

32. St Pierre, J.; Beis, S.; Van Heiningen, A., 2015: Pyrolysis of hardwood soda-anthraquinone spent pulping liquor. TAPPI Journal,14: 639-648. www.tappi.org

33. Wang, Z.; Cao, J.; Wang, J., 2009: Pyrolytic characteristics of pine wood in a slowly heating and gas sweeping fixed-bed reactor. Journal of Analytical and Applied Pyrolysis, 84 (2): 179-184. https://doi.org/10.1016/j.jaap.2009.02.001.

\section{Corresponding address:}

Assoc. Prof. AYBEN KILIÇ PEKGÖZLÜ, Ph.D.

Bartin University, Faculty of Forestry

Department of Forest Industry Engineering 74100, Bartin, TURKEY

e-mail: akilic@bartin.edu.tr 